\title{
AEC Impact on Investment and Production of Automobile Industry: Toyota Motor Thailand Co., Ltd.
}

\author{
Sombun Meadhapithakwong \\ Toyota Motor Asia Pacific Engineering \& Manufacturing Co., Ltd. \\ sombun_mea@tmap-em.toyota-asia.com
}

\begin{abstract}
This report would study the impact of AEC on investment and production of automobile industry in Thailand by studying in Toyota Motor Thailand Co., Ltd. Even though, automobile industry utilizes machines or robots in production line. But this industry is still need to use labor from human whom are scarce in the current. Whenever AEC is fully operated, it will effect to labor can move freely in this region particularly Toyota has production base in worldwide. Toyota has production base and marketing in ASEAN 6 of 10 countries: Malaysia Philippines Indonesia Vietnam Singapore and Thailand. So Toyota will be impacted from AEC also. The objectives of this report are:

1. To study both positive impact and negative impact of AEC on investment and production of automobile industry in Thailand by studying in Toyota Motor Thailand Co., Ltd.

2. To study the readiness of Thai automobile industry for investment and production for AEC.

For content scope is to study the impact from AEC to investment and production of automobile industry and the readiness of Thailand automobile industry to AEC by selecting Toyota Motor Thailand Co., Ltd. be case study.

While population scope is to study the employee of Toyota Motor Thailand Co., Ltd. by focusing on supervisor and management level total 4,473 persons (Source: Toyota Motor Thailand Co., Ltd., September 2012) because employees of these levels have technical skill and conceptual skill. This report is survey research by questionnaire both open-end question and closed-end question.

The benefit of this report is to acknowledge ASEAN community background and the impact from AEC with Thailand automobile industry for finding out the solution and prepare the readiness for AEC. Moreover this report is for Thai's government to consider their policy.
\end{abstract}

Keywords: AEC, Impact, Investment and Production, Automobile Industry.

\section{Background and Necessity}

Now automobile is the important factor of human daily life because automobile is the vehicle for transportation and logistics from anyplace to another place not only people but also anything. Automobile sale volume increases every year particularly last year (2012) due to Thai government had policy about " 1 st car project" which effected to a lot of sale volume.
Moreover, many famous automobile company selects Thailand to be a center of automobile production in order to sell in domestic and export into other countries. It effects to not only automobile industry in Thailand continuously broaden but related industries such as parts industry broaden also. Whenever automobile industry is growth, gross domestic product (GDP) is growth also. (See in the picture 1) 


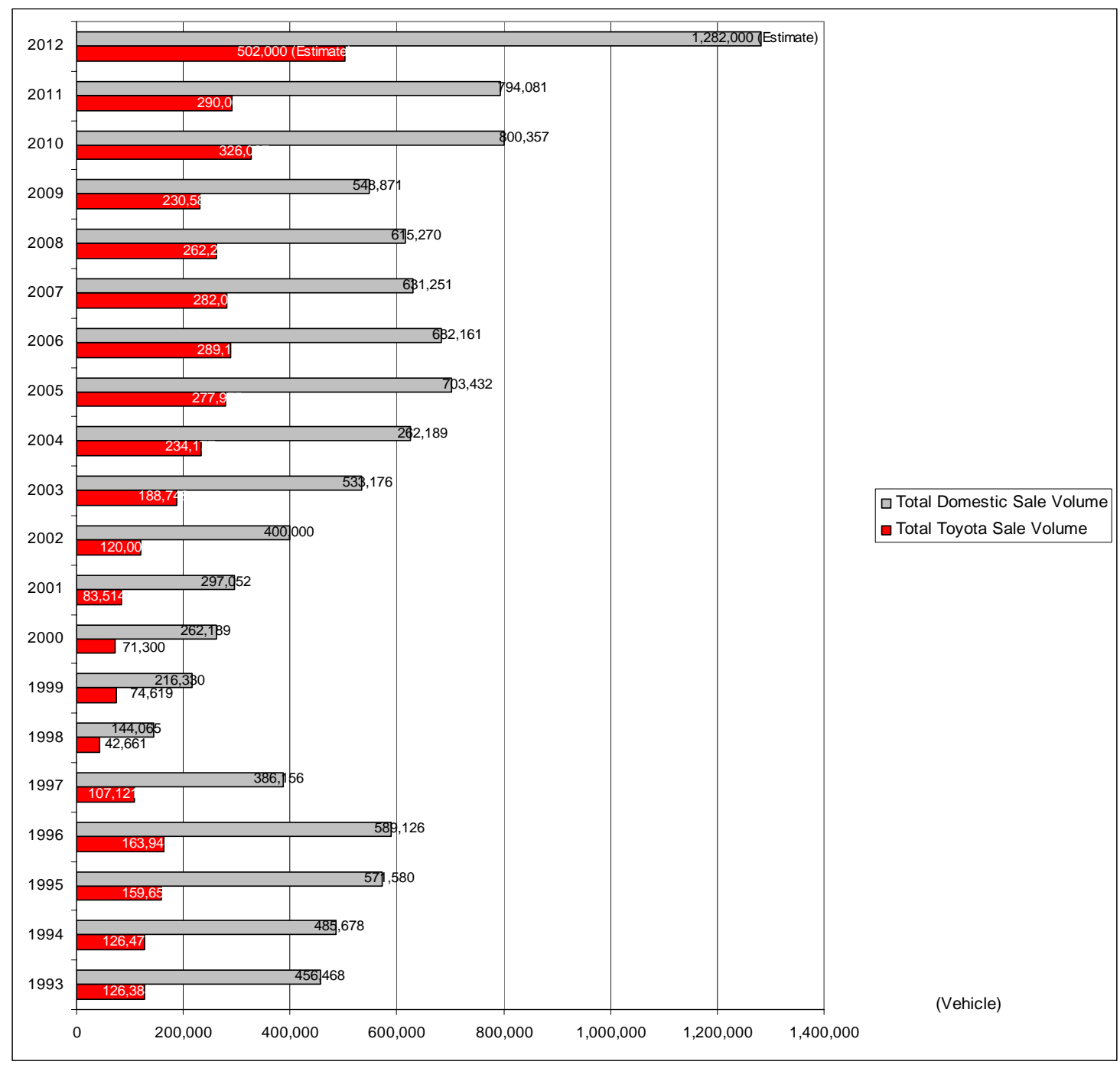

Figure 1 The Growth of Automobile Industry in Thailand during 1993-2012

Besides, Thai government has many policy to support automobile industry continuously until this industry success.

Whenever economic is growth continuously, it impacts on investment in automobile industry. This industry lacks of production materials and manpower or labor. Even though nowadays most of automobile industries in Thailand use robots or machines to produce in production line but industries are still need to use manpower in production line also. However, ASEAN Economic Community (AEC) will fully utilize in 2015, labor in ASEAN can move freely that may reduce labor scarcity particularly engineer in this industry.

Toyota has production and marketing base worldwide particularly Toyota has production and marketing base in ASEAN 6 of 10 countries: Thailand, Malaysia, Philippines, Indonesia, Vietnam and Singapore. So when AEC is fully utilized, it impacts on Toyota also.

\section{Objectives}

1) To study both positive impact and negative impact of AEC on investment and production of automobile industry in Thailand by studying in Toyota Motor Thailand Co., Ltd.

2) To study the readiness of Thai automobile industry of investment and production for AEC.

\section{Research Literature Review}

Boontharika Tubtimthong (2005, Summary) studied the "Impact of Free Trade Area (FTA) on Thai's Rice Trading”. The objective was to study turning point and direction of Thai's rice trading under FTA agreement and studied both positive impact and negative impact. The study used qualitative research in documentary and interviewing with rice experts, rice merchants, representative of Thai farmer association by 
applying public policy theory. The results of this study indicated that the positive impacts occurred from producers could sell rice higher than the previous, got the support of rice pedigree improvement and rice exporter could broaden to other markets.

For negative impacts were production cost was still high, farmer income was not related with production cost \& quality of rice and price competition with competitor countries in the market. The solution of negative impacts were to depend on government's role to support any facilities and benefits to concerned parties with this policy.

The $7^{\text {th }}$ Master of Public Administration of Burapha university (2004) studied in "Impact of Free Trade Area (FTA) with United State of America, Australia, China, India and Japan”. The objective was to study the impact from FTA from government officers, entrepreneurs, academicians, mass mediums and related persons. Moreover this report was to show countermeasure or solution of the impact. The study used qualitative research by in-depth interview and documentary with concerned parties focusing on trading between Thailand and U.S.A., Australia, China, India and Japan. The results of trading between Thailand and Australia found that Thailand got benefit in the industrial goods more than agriculture goods due to Thailand goods standard rating, value added in goods, management. The result of trading between Thailand and China was reduction of tariff of vegetables \& fruits about "rules of origin" must prove domestic production process by utilizing wholly obtained. It impacted on Thai exports directly due to un-readiness of Thai entrepreneurs initially. Thai government should communicate rules and acts in order to prepare the readiness of Thai entrepreneurs. While the result of trading between Thailand and India found that Thailand got benefits in reducing tariff of gems and accessories but Thailand might loss in changing cost which India got this benefit. Moreover Thailand got more export plastic materials and plastic goods to India because of Thai's quality. The results of trading between Thailand and Japan in industrials and agricultural goods found that Thai agricultural goods got the benefit but industrial goods found that Thailand was unreadiness to make FTA with Japan due to order materials and technology from foreign in order to produce industrial goods. The results of trading between Thailand and U.S.A. focusing on intelligence goods and agricultural goods found that Thailand should develop technology in the intelligence goods due to not able to compete with U.S.A. particularly bio- technology. In case of agriculture including GMO vegetables found that Thailand was discriminated from U.S.A. in term of hygiene of agricultural goods. So Thailand should more negotiated about reducing laws, rules, regulations and processes for exporting. For GMO goods, Thailand was not suitable to make FTA with developed countries due to Thailand was just under studying for GMO goods.

Somkiat Tungkitwanij, Dharadhorn Rattananaruemitsorn and Nuttawut Laksanapanyakul (2007) studied in "The Readiness of Thailand for Free Trade Area Agreement between Thailand and Europe Union (EU) under Trading and Investment”. The objective was to study and analyze role and way of Europe Union and to study possibility way of ASEAN in term of negotiation including the readiness of Thailand and impact from this agreement in order to find out the proper solution for proposing to Thailand negotiation committee. The overall image of this study found that AFAS agreement method was conform with agreement of Europe Union's bilateralness but different with agreement of U.S.A.'s bilateralness. While EU would make free trade area in all except service in audio-visual, air cargo both domestic \& international and domestic barge. The impacts of FTA between Thailand and EU effected to some entrepreneurs of telecommunication service, financial and energy but Thai's SME might get the benefit from this FTA. The impact of FTA between Thailand and EU in term of production had a little bit impact because Thailand has had open policy to support foreigner for investing in Thailand. The suggestion for negotiation and countermeasure were to issue law for international trading agreement by government, should negotiate with EU to accept ASEAN career standard particularly engineering field and should consider to increase any service field in infrastructure that concerned with production and economic such as telecommunication logistic and energy in order to compete with competitions and got more benefits to Thai's customers.

After reviewed the research above, I found that the impact of AEC on automobile industry was the investment and production particularly dimension of labor. Even though the current automobile industry has developed robot to work instead of labor but this industry is still need to use labor to produce vehicle especially in developing countries in ASEAN because of labor cost in ASEAN is cheaper than 
developed countries such as Japan, Europe, U.S.A., etc.

So, I would like to study the impact of AEC on automobile industry by focusing on investment and production in term of labor and study the readiness of Thailand automobile industry before AEC in 2015 by selecting case study from Toyota Motor Thailand Co.,Ltd. This study will get the information from employee of Toyota Motor Thailand in supervisor and management level by sampling 400 of 4,473 persons because they have technical skill and conceptual skill. While I will not get the information from operators due to most of them have human skill which not match with the objectives.

\section{References}

[1] Boontharika Tubtimtong. (2005). Impact of Free Trade Area (FTA) with Thai's Rice Trading. Independent Study of Graduate School of Public Administration, Burapha University.

[2] Somkiat Tungkitwanij and team. (2007). The Readiness of Thailand for Free Trade Area Agreetment between Thailand and Europe Union (EU) under Trading and Investment in Somkiat Tungkitwanij and Team (Editor), (pp. i-vii).

[3] The $7^{\text {th }}$ MPA of Burapha University. (2004). Free Trade Area between Thailand and United State of America Australia China India and Japan in Saruti Sakulrat (Editor), (pp. 1-150). 